\title{
Ellenségből barát - vagy jogos-e a xenofóbia?
}

„That would make good of bad, and friends of foes!" (Shakespeare: Macbeth)

\section{László-Bencsik Ábel*, Szatmáry Miklós}

Fitoherb Kft., 1066 Budapest, Teréz krt. 40.

*e-mail: laszlobencsik@fitoherb.hu

Az inváziós növényfajok (Balogh Lajos találó magyarításával: özönnövények) ma egyértelmúen az ellenségeink, noha e nem kívánatos jövevények hasznossá tételének szándéka többször és több szinten is megfogalmazódott. Hatályos gyógyszerkönyvünk is megjelöl invazívként ismert drogforrást (pl. aranyvessző).

Vajon érdemes-e folytatni a sort? Addig a lépésig mindenképpen, hogy legalább a bennük leír hatóanyagok potenciális gyógyászati lehetőségeit számon tartsuk. Ebben a vonatkozásban néhány példát említek:

- a japán keserüfú és hibridje (Fallopia japonica, F. $x$ bohemica) stilbénszármazékai,

- a keskenylevelü ezüstfa (Elaeagnus angustifolia) illóolaja, zsírosolaja, flavonoidjai és alkaloidjai,

- a kaukázusi medvetalp (Heracleum mantegazzianum) kumarinjai és illóolaja,

- a gyalogakác (Amorpha fruticosa) rotenoidjai,

- végül az ailanthon a mirigyes bálványfából (Ailanthus altissima).

Az említett hatóanyagok ugyanakkor nem csak gyógyászati szempontból lehetnek érdekesek, de - invazív fajok ökológiai hadviselésének fegyvereiként tekintve - pozitív vagy negatív szerepet játszhatnak a konzervációbiológia szempontjából is (allelopátia vagy természetes peszticidek). 